\title{
EFFECT OF NANOFLUID ON HEAT TRANSFER CHARACTERISTICS OF DOUBLE PIPE HEAT EXCHANGER: PART-I: EFFECT OF ALUMINUM OXIDE NANOFLUID
}

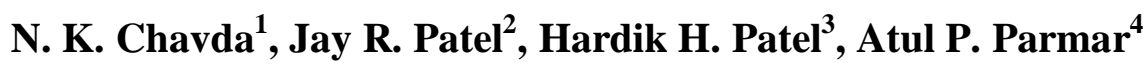 \\ ${ }^{I}$ Corresponding Author, Associate Professor, Department of Mechanical Engineering, A. D. Patel Institute of \\ Technology, New Vallabh Vidyanagar - 388121 \\ ${ }^{2} U G$ Student, Department of Mechanical Engineering, A. D. Patel Institute of Technology, New Vallabh Vidyanagar- \\ 388121 \\ ${ }^{3} U G$ Student, Department of Mechanical Engineering, A. D. Patel Institute of Technology, New Vallabh Vidyanagar- \\ 388121 \\ ${ }^{4} U G$ Student, Department of Mechanical Engineering, A. D. Patel Institute of Technology, New Vallabh Vidyanagar- \\ 388121
}

\begin{abstract}
A nanofluid is a mixture of nano sized particles of size up to $100 \mathrm{~nm}$ and a base fluid. Typical nanoparticles are made of metals, oxides or carbides, while base fluids may be water, ethylene glycol or oil. The effect of nanofluid to enhance the heat transfer rate in various heat exchangers is experimentally evaluated recently. The heat transfer enhancement using nanofluid mainly depends on type of nanoparticles, size of nanoparticles and concentration of nanoparticles in base fluid. In the present paper, an experimental investigation is carried out to determine the effect of various concentration of $\mathrm{Al}_{2} \mathrm{O}_{3}$ nano-dispersion mixed in water as base fluid on heat transfer characteristics of double pipe heat exchanger for parallel flow and counter flow arrangement. The volume concentrations of $\mathrm{Al}_{2} \mathrm{O}_{3}$ nanofluid prepared are $0.001 \%$ to $0.01 \%$. The conclusion derived for the study is that overall heat transfer coefficient increases with increase in volume concentration of $\mathrm{Al}_{2} \mathrm{O}_{3}$ nano-dispersion compared to water up to volume concentration of $0.008 \%$ and then decreases.
\end{abstract}

Keywords: Nanofluid, Heat Transfer Characteristics, Double Pipe Heat Exchagner, $\mathrm{Al}_{2} \mathrm{O}_{3} \mathrm{Nano}_{\text {-dispersion }}$

\section{INTRODUCTION}

Different types of heat exchangers are extensively used in various industries to transfer the heat between cold and hold stream. The key role of the heat exchanger is to transfer heat at maximum rate. The enhancement in heat transfer rate is possible to achieve by two steps viz. (1) to optimize the design of the heat exchanger and (2) to optimize the operational parameters. To optimize the operational parameters play a key role in enhancement of heat transfer rate after the design of heat exchanger.

The method of enhancement of heat transfer rate operationally is broadly divided as (1) active methods and (2) passive methods. Active method includes electro hydrodynamics, jets, sprays, ultrasound waves, synthetic jet heat transfer and high amplitude vibratory motion, while passive method include surface coating, nanoscale coating, nanofluid, hydrodynamic cavitations, turbulence promoters and mixing promoters [1]. Among them, three methods are considered as effective methods to enhance the heat transfer which are (1) utilizing nanofluids, (2) inserting fluid tabulators and (3) roughing the heat exchanger surface. A nanofluid is a mixture of nano sized particles and a base fluid. Typical nanoparticles are made of metals, oxides or carbides, while base fluids may be water, ethylene glycol or oil. The nanofluid exhibits different thermo physical properties than the base fluid. Generally thermal conductivity of nanofluids is higher than the base fluid which increases the heat transfer rate. The heat transfer enhancement using nanofluid mainly depends on type of nanoparticles, size of nanoparticles and concentration of nanoparticles in base fluid.

A comprehensive review of published papers in last ten years and available in open literature related to the application of nanofluid in heat transfer has been carried out. Out of total twenty nine research papers, ten research papers [2-11] are related to double pipe heat exchanger, six research papers [12-17] are in the field of shell and tube heat exchanger, twelve studies [18-29] are in other type of heat exchangers and one [30] in the field of phase change material. Nine researchers $[2-6,13,16,25,26]$ have utilized $\mathrm{A} 12 \mathrm{O} 3$ based nanofluid, three [7, 8, 10] have employed TiO2 based nanofluid, while two - two studies are carried out using $\mathrm{CuO} 2[24,30]$, MWCNT $[14,22]$ and Fe2O3 [9, 20] based nanofluids. The detailed review of published papers pertaining to application of nanofluid in heat exchanger is presented below. 
W. A. Aly [2] has carried out computational fluid dynamics (CFD) analysis to study the heat transfer and pressure drop characteristics of water-based $\mathrm{Al} 2 \mathrm{O} 3$ nanofluid flowing inside coiled tube-in-tube heat exchangers. He found that the heat transfer coefficient increases by increasing the coil diameter and nanoparticles volume concentration while, friction factor increases with the increase in curvature ratio. Their results validated the Gnielinski correlation and Mishra and Gupta correlation for predicting average heat transfer and friction factor in turbulent flow regime and they have found that nanofluids behave like a homogeneous fluid. Rabienataj Darzi A. A. and et. al. [3] have carried out an experimental study in order to find out the effects of $\mathrm{Al}_{2} \mathrm{O}_{3}$ nanofluid, having nanoparticles concentration up to $1 \%$ by volume and mean diameter of $20 \mathrm{~nm}$, on heat transfer, pressure drop and thermal performance of a double tubes heat exchanger. They have established the empirical correlation for Nusselt number variation based on the Reynolds number and nanoparticles concentration. Akhtari, M. and et. al. [4] have performed an experimental and numerical study on the heat transfer of $\alpha-\mathrm{Al} 2 \mathrm{O} 3 /$ water nanofluid flowing through the double pipe and shell and tube heat exchangers, under laminar flow conditions. They have found that the heat transfer performance of both double pipe and shell and tube heat exchangers increases with increasing the hot and cold volume flow rates, as well as the particle concentrations and nanofluid inlet temperature as compared with pure water.

Aghayari, R. and et. al. [5] have investigated the heat transfer of a fluid containing nanoparticles of aluminum oxide with a diameter of about $20 \mathrm{~nm}$, with the water volume fraction $(0.1-0.3)$ percent in a horizontal double pipe counter flow heat exchanger under turbulent flow conditions. They have found that heat transfer of nanofluid in comparison with the heat transfer of fluid is slightly higher than $12 \%$. Chun, B. H. and et. al. [6] have investigated the convective heat transfer coefficient of nanofluids made of alumina nanoparticles and transformer oil which flow through a double pipe heat exchanger system in the laminar flow regime. They have proposed an experimental correlation for an alumina-transformer oil nanofluid system to understand the enhancement of heat transfer of nanofluid.

Duangthongsuk, W. and Wongwises, S. [7] have carried out an experimental study on the forced convective heat transfer coefficient and friction factor of a nanofluid consisting of water and $0.2 \mathrm{vol} . \% \mathrm{TiO} 2$ nanoparticles of about $21 \mathrm{~nm}$ diameter flowing in a horizontal double-tube counter flow heat exchanger under turbulent flow conditions. They have found that the heat transfer coefficient of the nanofluid increases with an increase in the mass flow rate of the hot water and nanofluid, and increases with a decrease in the nanofluid temperature. They have also observed that the Gnielinski equation failed to predict the heat transfer coefficient of the nanofluid.

Khedkar, R. S. and et. al. [8] have studied the heat-transfer characteristics of $\mathrm{TiO}_{2}-$ water nanofluids as a coolant in concentric tube heat exchanger. They considered the effects of inlet flow rate of hot fluids, Reynold's number and composition of nanofluids on concentric tube heat exchanger. They found that the average heat transfer rates increases with concentration of nanofluid composition. Bahiraei, M. and Hangi, M. [9] have investigated the performance of water based $\mathrm{Mn}-\mathrm{Zn}$ ferrite magnetic nanofluid in a counter-flow double-pipe heat exchanger under quadrupole magnetic field using the two-phase EulerLagrange method. They have examined the effects of different parameters including concentration, size of the particles, magnitude of the magnetic field and Reynolds number. Chandra Sekhara Reddy, M. and Veeredhi Vasudeva Rao [10] have investigated the heat transfer coefficient and friction factor of $\mathrm{TiO} 2$ nanofluid having volume concentration range from $0.0004 \%$ to $0.02 \%$ in a base fluid having $40 \%$ of ethylene glycol and $60 \%$ of distilled water, flowing in a double pipe heat exchanger with and without helical coil inserts.

Liu, L and et. al. [11] have reported the potential benefit of using nanofluids in heat-exchanger applications is explored using an $\alpha$-NTU analysis. They have found that among all flow arrangements investigated, the concentric-tube, counterflow arrangement shows highest improvement in heat duty for a prescribed convective heat-transfer enhancement. Elias, M. M. and et. al. [12] have studied the effect of different particle shapes (cylindrical, bricks, blades, and platelets) on the overall heat transfer coefficient, heat transfer rate and entropy generation of shell and tube heat exchanger with different baffle angles and segmental baffle.

Albadr, J. and et. al. [13], Lotfi, R. and et. al. [14], Leong, K. Y. and et. al. [15], Bahiraei, M. and et. al. [16] and Shahrul, I. M. and et. al. [17] have presented experimental studies on application of nanofluid in shell and tube heat exchanger. Various researchers have studied the effect of nanofluid on plate heat exhchanger [18, 21, 22], micro-pinfin heat exchanger [19], an air-finned heat exchanger [20], corrugated plate heat exchanger [23], plate-fin channels [24], helical coil heat exchanger [25, 28], multi-channel heat exchanger [26] and micro-heat pipe array heat exchanger [27].

The review of literature reveals the facts related to the application of nanofluid in heat exchanger for enhancement of heat transfer rate that (1) Nanofluids are the relatively recent practice to enhance the heat transfer rate, (2) There are different types of nanofluids which can be used to enhance the heat transfer rate and (3) Many researchers have carried out numerical and experimental analysis on application of nanofluid in enhancement of heat transfer rate under different conditions. Extensive experiments have been carried out on double pipe heat exchanger to determine the effect of different type of nanofluids (having nanoparticles of $\mathrm{Al}_{2} \mathrm{O}_{3}$ and $\mathrm{CuO}$.) and concentration of nanoparticles in nanofluid during parallel and counter flow condition. In the part $\mathrm{I}$ of the paper, effect of $\mathrm{Al}_{2} \mathrm{O}_{3}$ nanofluid has been presented and in the part II of the paper effect of $\mathrm{CuO}$ nanofluid has been presented. 


\section{EXPERIMENT SETUP AND PROCEDURE}

Apparatus for double pipe heat exchanger is shown in Figure 1. The outer pipe is made up of SS 304 material having outer diameter, inner diameter and length of $36 \mathrm{~mm}$, $32 \mathrm{~mm}$ and $3 \mathrm{~m}$ respectively. The inner pipe is also made up of SS 304 having outer diameter, inner diameter and length of $18 \mathrm{~mm}, 15 \mathrm{~mm}$ and $3 \mathrm{~m}$ respectively. Cladding of mineral wool having $25 \mathrm{~mm}$ thickness is carried out which acts as insulation over outer pipe. Two valves are provided on each pipe which can be open and closed alternatively for counter and parallel flow operation. Two water tanks viz. (1) Cold
Water and (2) Hot Water are provided with separate SS 304 mono-block type centrifugal pump to circulate cold and hot water through pipes respectively. Three immersion type heaters, each of $6 \mathrm{~kW}$ capacity are located in hot water tank to heat the water. Two Fitzer make rotameters, each of $0.5-$ $5.0 \mathrm{lpm}$ range are connected to measure the flow rate of cold water and hot water from the pipes. $J$ type thermocouples are used to measure the inlet and outlet temperatures of cold and hot water flowing through the pipes. Digital temperature indicator is provided to indicate the temperature.

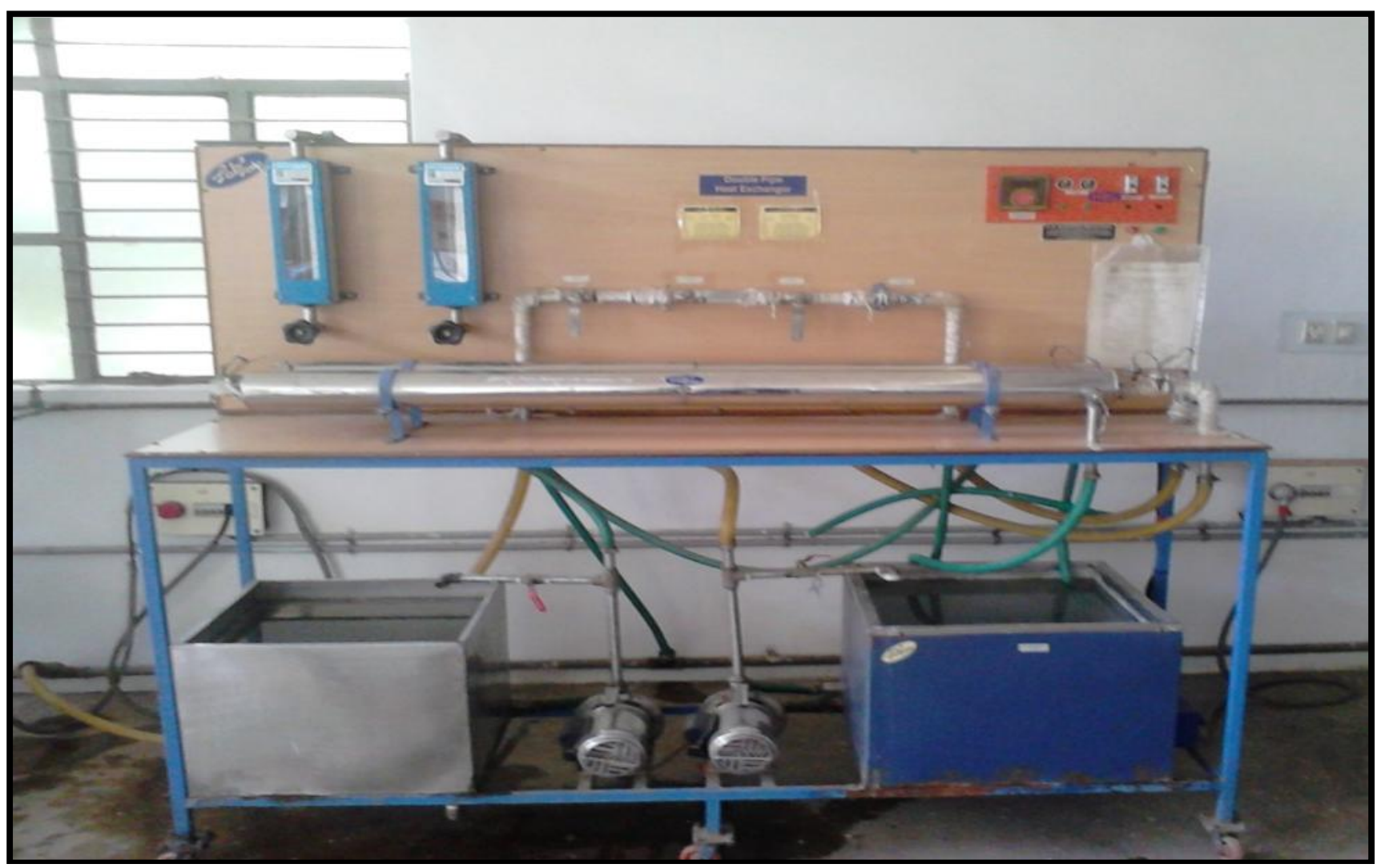

Fig 1: Experimental Setup: Double Pipe Heat Exchanger Apparatus

\subsection{Experimental Procedure for Double Pipe Heat}

\section{Exchanger}

(1) Fill water in cold and hot water tank.

(2) Switch on the immersion type heater provided in the hot water tank and heat the water to the desired temperature.

(3) Switch "ON" the pump provided in hot water tank with bypass line valve fully open and supply valve fully closed to ensure thorough mixing of water in the tank to ensure uniform temperature.

(4) Operate valves out of four valves provided on the panel in such a manner that the heat exchanger operates in parallel flow mode.

(5) Allow the hot water to flow through inner pipe side. Adjust the flow rate to the desired value using the rotameter.
(6) Start the cold water supply on the outer pipe side. Adjust the flow rate to the desired value using rotameter.

(7) Observe the inlet and outlet temperature of both cold and hot water streams and record them after they achieve steady state condition.

(8) Record the flow rates of hot water and cold water with the help of rotameters.

(9) Repeat the procedure step number 6 to 9 for different flow rates of cold and hot water.

(10) Alter the opening of valves out of four valves provided on the panel in such a manner that now, the heat exchanger operates in parallel flow mode.

(11) Repeat the procedure step number 6 to 10 for counter flow arrangement of double pipe heat exchanger.

(12) Drain the water from both the tanks after completion of experiments. 


\subsection{Calculation Steps for Double Pipe Heat} Exchanger

The methodology adopted for calculation for experimentation and theoretical evaluation of overall heat transfer coefficient for double pipe heat exchanger for parallel and counter flow arrangements are described in subsection 2.2 .1 and 2.2.2 respectively.

\subsubsection{Calculation Steps for Experimental}

\section{Evaluation of Overall Heat Transfer Coefficient}

(1) Flow Rate of Hot Water

$$
\mathrm{m}_{\mathrm{H}}=\mathrm{m}_{\mathrm{h}} \times \frac{\rho_{\mathrm{h}}}{60}
$$

(2) Flow Rate of Cold Water

$$
\mathrm{m}_{\mathrm{C}}=\mathrm{m}_{\mathrm{c}} \times \frac{\rho_{\mathrm{c}}}{60}
$$

(3) Heat Transferred by Hot to Cold Water

$$
\mathrm{Q}_{\mathrm{h}}=\mathrm{m}_{\mathrm{H}} \times \mathrm{C}_{\mathrm{p}, \mathrm{h}}\left(\mathrm{T}_{\mathrm{hi}}-\mathrm{T}_{\mathrm{ho}}\right)
$$

(4) Heat Transferred by Cold to Hot Water

$$
\mathrm{Q}_{\mathrm{c}}=\mathrm{m}_{\mathrm{C}} \times \mathrm{C}_{\mathrm{p}, \mathrm{c}}\left(\mathrm{T}_{\mathrm{co}}-\mathrm{T}_{\mathrm{ci}}\right)
$$

(5) Average Heat Transfer

$$
Q_{\text {avg }}=\frac{Q_{h}+Q_{c}}{2}
$$

(6) Outer Surface Area of Inner Pipe

$$
\mathrm{A}_{\mathrm{os}, \mathrm{ip}}=\pi \times \mathrm{d}_{0, \mathrm{ip}} \times \mathrm{L}
$$

(7) Inner Surface Area of Inner Pipe

$$
\mathrm{A}_{\mathrm{is,ip}}=\pi \times \mathrm{d}_{\mathrm{i}, \mathrm{ip}} \times \mathrm{L}
$$

(8) Logarithmic Mean Temp. Difference

For Parallel Flow Arrangement

$$
\operatorname{LMTD}=\frac{\left(\mathrm{T}_{\mathrm{hi}}-\mathrm{T}_{\mathrm{ci}}\right)-\left(\mathrm{T}_{\mathrm{h} 0}-\mathrm{T}_{\mathrm{co}}\right)}{\ln \left\{\frac{\left(\mathrm{T}_{\mathrm{hi}}-\mathrm{T}_{\mathrm{ci}}\right)}{\left(\mathrm{T}_{\mathrm{h} 0}-\mathrm{T}_{\mathrm{co}}\right)}\right\}}
$$

For Counter Flow Arrangement

$$
\operatorname{LMTD}=\frac{\left(\mathrm{T}_{\mathrm{hi}}-\mathrm{T}_{\mathrm{c} 0}\right)-\left(\mathrm{T}_{\mathrm{h} 0}-\mathrm{T}_{\mathrm{ci}}\right)}{\ln \left\{\frac{\left(\mathrm{T}_{\mathrm{hi}}-\mathrm{T}_{\mathrm{c} 0}\right)}{\left(\mathrm{T}_{\mathrm{h} 0}-\mathrm{T}_{\mathrm{ci}}\right)}\right\}}
$$

(9) Overall Heat Transfer Coefficient based on Outer Surface Area of Inner Pipe

$$
\mathrm{U}_{\mathrm{o}, \text { pract }}=\frac{\mathrm{Q}_{\mathrm{avg}}}{\mathrm{A}_{\mathrm{os}, \mathrm{ip}} \times \mathrm{LMTD}}
$$

(10) Overall Heat Transfer Coefficient based on Inner Surface Area of Inner Pipe

$$
\mathrm{U}_{\mathrm{i} \text {,pract }}=\frac{\mathrm{Q}_{\mathrm{avg}}}{\mathrm{A}_{\mathrm{is,ip}} \times \mathrm{LMTD}}
$$

\subsubsection{Calculation Steps for Theoretical Evaluation} of Overall Heat Transfer Coefficient

(1) Average Temperature of Cold Water

$$
\mathrm{T}_{\mathrm{avg}, \mathrm{c}}=\frac{\mathrm{T}_{\mathrm{ci}}+\mathrm{T}_{\mathrm{co}}}{2}
$$

(2) Average Temperature of Hot Water

$$
\mathrm{T}_{\mathrm{avg}, \mathrm{h}}=\frac{\mathrm{T}_{\mathrm{hi}}+\mathrm{T}_{\mathrm{ho}}}{2}
$$

(3) Obtain Following Parameters of Cold Water at Average Temperature of Cold Water

$$
\text { Density, } \rho_{c} ; \text { Specific Heat, } C_{p, c} \text {; }
$$

Dynamic Viscosity, $\mu_{c} ;$ Prandtl No.,$P_{r, c}$

$$
\text { and Thermal Conductivity, } k_{c} \text {. }
$$

(4) Obtain Following Parameters of Hot Water at Average Temperature of Hot Water

$$
\text { Density, } \rho_{h} ; \text { Specific Heat, } C_{p, h} \text {; }
$$

Dynamic Viscosity, $\mu_{h} ;$ Prandtl No.,$P_{r, h}$

$$
\text { and Thermal Conductivity, } k_{h} \text {. }
$$

(5) Heat Capacity Flow Rate of Cold Water

$$
\mathrm{C}_{\mathrm{c}}=\mathrm{m}_{\mathrm{C}} \times \mathrm{C}_{\mathrm{p}, \mathrm{c}}
$$

(6) Heat Capacity Flow Rate of Hot Water

$$
\mathrm{C}_{\mathrm{h}}=\mathrm{m}_{\mathrm{H}} \times \mathrm{C}_{\mathrm{p}, \mathrm{h}}
$$

(7) Minimum Heat Capacity Flow Rate

$$
\mathrm{C}_{\text {min }}=\text { Minimum Value out of } \mathrm{C}_{\mathrm{c}} \text { and } \mathrm{C}_{\mathrm{h}}
$$

(8) Minimum Heat Capacity Flow Rate

$$
\mathrm{C}_{\max }=\text { Maximum Value out of } \mathrm{C}_{\mathrm{c}} \text { and } \mathrm{C}_{\mathrm{h}}
$$


(9) Maximum Possible Heat Transfer

$$
\mathrm{Q}_{\max }=\mathrm{C}_{\min }\left(\mathrm{T}_{\mathrm{hi}}-\mathrm{T}_{\mathrm{ci}}\right)
$$

(10) Effectiveness of the Heat Exchanger

$$
\epsilon=\frac{Q_{\text {avg }}}{Q_{\max }}
$$

(11) Cross Sectional Area of Annulus through which Cold Water Flows

$$
A_{\text {annulus }}=\frac{\pi}{4} \times\left(d_{i, o p}{ }^{2}-d_{o, i p}{ }^{2}\right)
$$

(12) Velocity of Cold Water

$$
\mathrm{V}_{\mathrm{c}}=\frac{\mathrm{m}_{\mathrm{C}}}{\rho_{\mathrm{c}} \times \mathrm{A}_{\text {annulus }}}
$$

(13) Characteristics Diameter of Cold Water

$$
D_{c}=\left(d_{i, o p}-d_{o, i p}\right)
$$

(14) Reynolds Number for Cold Water Flow

$$
\mathrm{R}_{\mathrm{e}, \mathrm{c}}=\frac{\rho_{\mathrm{c}} \times \mathrm{V}_{\mathrm{c}} \times \mathrm{D}_{\mathrm{c}}}{\mu_{\mathrm{c}}}
$$

(15) Nusselt Number for Cold Water Flow

$$
\mathrm{N}_{\mathrm{u}, \mathrm{c}=} 3.657+\frac{0.0677 \times\left(\mathrm{R}_{\mathrm{e}, \mathrm{c}} \times \mathrm{P}_{\mathrm{r}, \mathrm{c}} \times \frac{\mathrm{D}_{\mathrm{c}}}{\mathrm{L}}\right)^{1.33}}{1+\left(0.1 \times \mathrm{P}_{\mathrm{r}, \mathrm{c}}\right) \times\left(\mathrm{R}_{\mathrm{e}, \mathrm{c}} \times \frac{\mathrm{D}_{\mathrm{c}}}{\mathrm{L}}\right)^{0.33}}
$$

for $\mathrm{R}_{\mathrm{e}, \mathrm{c}}<2300$

$$
\mathrm{N}_{\mathrm{u}, \mathrm{c}=} \frac{\frac{f}{8} \times\left(\mathrm{R}_{\mathrm{e}, \mathrm{c}}-1000\right) \times \mathrm{P}_{\mathrm{r}, \mathrm{c}}}{1+12.7 \times\left\{\frac{f}{8}\right\}^{0.5} \times\left\{\left(\mathrm{P}_{\mathrm{r}, \mathrm{c}}\right)^{0.666}-1\right\}}
$$

for $\mathrm{R}_{\mathrm{e}, \mathrm{c}}>2300$

where, $f=\left(1.82 \times \log _{10} \mathrm{R}_{\mathrm{e}, \mathrm{c}}-1.64\right)^{-2}$

(16) Nusselt Number for $\mathrm{Al}_{2} \mathrm{O}_{3}$ Nanofluid Flow [31]

$$
\begin{aligned}
\mathrm{N}_{\mathrm{u}, \mathrm{c}=} 4.36+\{\mathrm{a} \times & \mathrm{x}_{\text {new }}^{-\mathrm{b}} \times\left(1+\emptyset^{\mathrm{c}}\right) \times \exp ^{\left.-\mathrm{d} \times \mathrm{x}_{\text {new }}\right\}} \\
& \times\left\{1+\text { valueof"e" } \times\left(\frac{\mathrm{d}_{\text {nanoparticle }}}{\mathrm{d}_{\text {ref }}}\right)^{-\mathrm{f}}\right\}
\end{aligned}
$$

$500<\mathrm{R}_{\mathrm{ec}}<2000 \& \emptyset$ upto $4 \%$

Where,

\begin{tabular}{|l|l|l|}
\hline $\mathrm{a}=6.219 \times 10^{-3}$ & $\mathrm{~d}=2.5228$ & $\mathrm{~d}_{\mathrm{ref}}=100 \mathrm{~nm}$ \\
\hline $\mathrm{b}=1.1522$ & $\mathrm{e}=0.57825$ & $\begin{array}{l}\mathrm{d}_{\mathrm{np}}=\text { Dia. of Nano } \\
\text { Particles }=50 \mathrm{~nm}\end{array}$ \\
\hline $\mathrm{c}=0.1533$ & $\mathrm{f}=0.2183$ & $\mathrm{x}_{\text {new }}=\mathrm{x} /\left(\mathrm{R}_{\mathrm{e}} * \mathrm{P}_{\mathrm{r}} * \mathrm{D}_{\mathrm{c}}\right)$ \\
\hline
\end{tabular}

$$
\mathrm{N}_{\mathrm{u}}=\frac{\left\{\left(\frac{f}{8}\right) \times\left(\mathrm{R}_{\mathrm{e}}-1000\right) \times \mathrm{P}_{\mathrm{r}}\right\}}{\left\{\delta \mathrm{V}_{\text {new }} \times\left(\frac{f}{8}\right)^{0.5} \times\left(\mathrm{P}_{\mathrm{r}}^{0.666}-1\right)\right\}}
$$

$5000<\mathrm{R}_{\mathrm{ec}}<65000$ and $\varnothing$ upto $3.6 \%$

where, $f=\left(1.82 \times \log _{10} R_{e, c}-1.64\right)^{-2}$

and $\delta \mathrm{V}_{\text {new }}=15.5$

(17) Heat Transfer Coefficient for Cold Water (Outside Heat Transfer Coefficient)

$$
\mathrm{h}_{\mathrm{c}}=\frac{\mathrm{N}_{\mathrm{u}, \mathrm{c}} \times \mathrm{k}_{\mathrm{c}}}{\mathrm{D}_{\mathrm{c}}}
$$

(18) Cross Sectional Area of Inner Pipe through which Hot Water Flows

$$
A_{c s, i p}=\frac{\pi}{4} \times\left(d_{i, i p}\right)^{2}
$$

(19) Velocity of Hot Water

$$
\mathrm{V}_{\mathrm{h}}=\frac{\mathrm{m}_{\mathrm{H}}}{\rho_{\mathrm{h}} \times \mathrm{A}_{\mathrm{cs}, \mathrm{ip}}}
$$

(20) Characteristics Diameter of Hot Water

$$
\mathrm{D}_{\mathrm{h}}=\mathrm{d}_{\mathrm{i}, \mathrm{ip}}
$$

(21) Reynolds Number for Hot Water Flow

$$
\mathrm{R}_{\mathrm{e}, \mathrm{h}}=\frac{\rho_{\mathrm{h}} \times \mathrm{V}_{\mathrm{h}} \times \mathrm{D}_{\mathrm{h}}}{\mu_{\mathrm{h}}}
$$

(22) Nusselt Number for Hot Water Flow

$$
\mathrm{N}_{\mathrm{u}, \mathrm{h}=} 3.657+\frac{\left\{\begin{array}{c}
0.0677 \times \\
\left(\mathrm{R}_{\mathrm{e}, \mathrm{h}} \times \mathrm{P}_{\mathrm{r}, \mathrm{h}} \times \frac{\mathrm{D}_{\mathrm{h}}}{\mathrm{L}}\right)^{1.33}
\end{array}\right\}}{\left\{\begin{array}{c}
1+\left(0.1 \times \mathrm{P}_{\mathrm{r}, \mathrm{h}}\right) \\
\times\left(\mathrm{R}_{\mathrm{e}, \mathrm{h}} \times \frac{\mathrm{D}_{\mathrm{h}}}{\mathrm{L}}\right)^{0.33}
\end{array}\right\}}
$$

for $\mathrm{R}_{\mathrm{e}, \mathrm{h}}<2300$

$$
\mathrm{N}_{\mathrm{u}, \mathrm{h}=} \frac{\frac{f}{8} \times\left(\mathrm{R}_{\mathrm{e}, \mathrm{h}}-1000\right) \times \mathrm{P}_{\mathrm{r}, \mathrm{h}}}{1+12.7 \times\{\overline{8}\}^{0.5} \times\left\{\left(\mathrm{P}_{\mathrm{r}, \mathrm{h}}\right)^{0.666}-1\right\}}
$$

for $R_{e, h}>2300$

where, $f=\left(1.82 \times \log _{10} \mathrm{R}_{\mathrm{e}, \mathrm{h}}-1.64\right)^{-2}$ 
(23) Heat Transfer Coefficient for Hot Water (Inside Heat Transfer Coefficient)

$$
\mathrm{h}_{\mathrm{h}}=\frac{\mathrm{N}_{\mathrm{u}, \mathrm{h}} \times \mathrm{k}_{\mathrm{h}}}{\mathrm{D}_{\mathrm{h}}}
$$

(24) Inner Overall Heat Transfer Coefficient

$$
\mathrm{U}_{\mathrm{i}, \text { theo }}=\frac{1}{\left\{\frac{1}{\mathrm{~h}_{\mathrm{h}}}\right\}+\left\{\frac{\mathrm{d}_{\mathrm{i} \text { ip }} / 2}{\mathrm{k}_{\mathrm{ip}}} \times \ln \left\{\frac{\mathrm{d}_{\mathrm{o}, \mathrm{ip}} / 2}{\mathrm{~d}_{\mathrm{i}, \mathrm{ip}} / 2}\right\}\right\}+\left\{\frac{\mathrm{d}_{\mathrm{i}, \mathrm{ip}} / 2}{\mathrm{~d}_{\mathrm{o}, \mathrm{ip}} / 2} \times \frac{1}{\mathrm{~h}_{\mathrm{c}}}\right\}}
$$

(25) Outer Overall Heat Transfer Coefficient

$$
=\frac{\mathrm{U}_{\mathrm{o}, \text { theo }}}{\left\{\frac{1}{\mathrm{~h}_{\mathrm{c}}}\right\}+\left\{\frac{\mathrm{d}_{\mathrm{o}, \mathrm{ip}} / 2}{\mathrm{k}_{\mathrm{ip}}} \times \ln \left\{\frac{\mathrm{d}_{\mathrm{o}, \mathrm{ip}} / 2}{\mathrm{~d}_{\mathrm{i}, \mathrm{i}} / 2}\right\}\right\}+\left\{\frac{\mathrm{d}_{\mathrm{o}, \mathrm{ip}} / 2}{\mathrm{~d}_{\mathrm{i}, \mathrm{i}} / 2} \times \frac{1}{\mathrm{~h}_{\mathrm{h}}}\right\}}
$$

\section{PREPARATION AND CHARACTERIZATION}

\section{OF NANOFLUID}

There are two techniques to prepare nanofluids viz. (1) the single-step method, in which nanoparticles are evaporated and directly dispersed into the base fluids and (2) the twostep method in which nanoparticles are made first and then disperses them into the base fluids. The basic requirement of preparation of nanofluid is to obtaine a well-mixed and uniformly dispersed nanofluid for successful reproduction of properties and interpretation of experimental data.

Two-step method has been employed to prepare nanofluid. $\mathrm{Al}_{2} \mathrm{O}_{3}$ nano-dispersion $(\mathrm{AlO}(\mathrm{OH}))$ has been purchased from $\mathrm{M} / \mathrm{s}$. Jyotirmay Overseas, Rajkot. $\mathrm{Al}_{2} \mathrm{O}_{3}$ nano-dispersion of $50 \mathrm{~nm}$ size has $1190 \mathrm{~kg} / \mathrm{m}^{3}$ density and $10 \mathrm{cps}$ viscosity. The proportion of $\mathrm{Al}_{2} \mathrm{O}_{3}$ nano-dispersion to be mixed with the base fluid i.e. water for different volume concentration is calculated using following equation. For different volume concentrations, the mass of nanoparticle to mix with the water is presented in Table 1.

$$
\begin{gathered}
\varnothing=\frac{\left\{\begin{array}{c}
\text { Volume of } \\
\text { Nanoparticle }
\end{array}\right\}}{\left\{\begin{array}{c}
\text { Volume of Nanoparticle } \\
+ \text { Volume of water }
\end{array}\right\}} \times 100 \\
\varnothing=\frac{\frac{\mathrm{W}_{\text {nanoparticle }}}{\rho_{\text {nanoparticle }}}}{\frac{\mathrm{W}_{\text {nanoparticle }}}{\rho_{\text {nanoparticle }}}+\frac{\mathrm{W}_{\text {water }}}{\rho_{\text {water }}}} \times 100
\end{gathered}
$$

Table 1: Mass of $\mathrm{Al}_{2} \mathrm{O}_{3}$ Nano-dispersion to Mix with Water for Different Volume Concentration

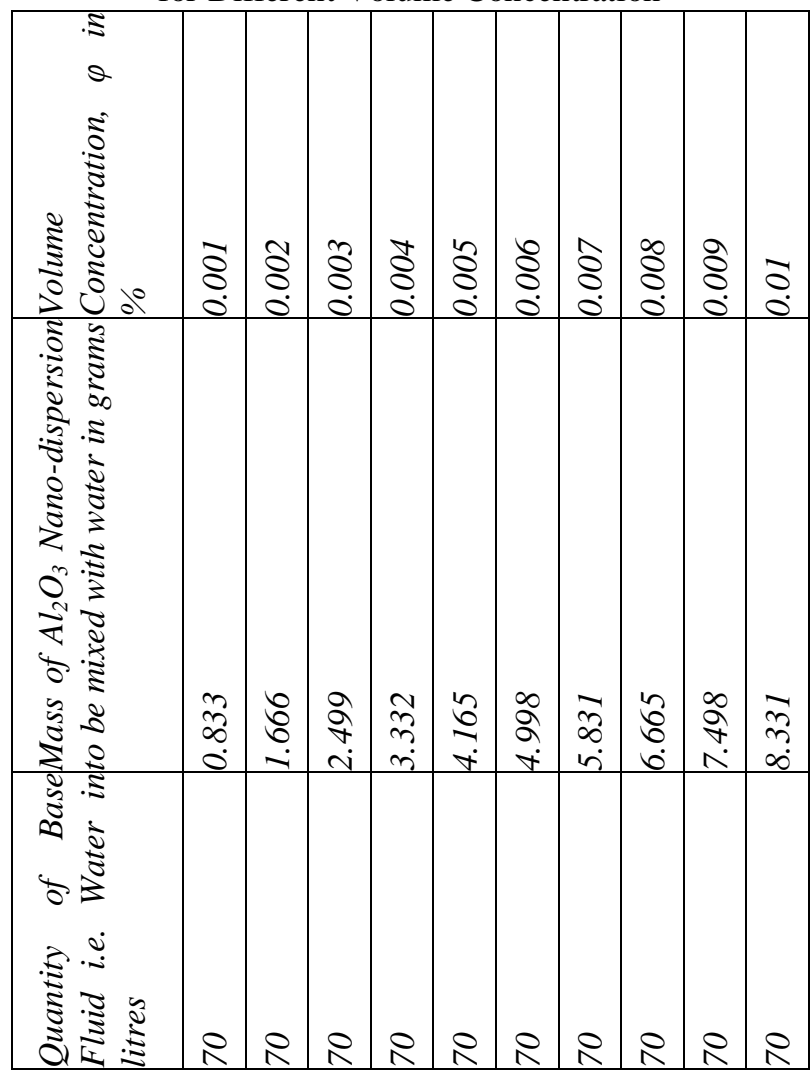

The following equations are used to determine the density, specific heat, dynamic viscosity, thermal conductivity and prandtl number of nanofluid respectively.

$$
\begin{aligned}
& \rho_{\text {nanofluid }}=\left\{\varnothing \times \rho_{\text {nanoparticle }}\right\}+\left\{(1-\emptyset) \rho_{\text {water }}\right\} \\
& C_{p, \text { nanofluid }}=\frac{\left[\begin{array}{c}
\emptyset \times\left\{\rho_{\text {nanoparticle }} \times C_{p, \text { nanoparticle }}\right\} \\
+(1-\emptyset) \times\left\{\rho_{\text {water }} \times C_{p, \text { water }}\right\}
\end{array}\right]}{\rho_{\text {nanofluid }}} \\
& \mu_{\text {nanofluid }}=\left\{1+(7.3 \times \emptyset)+\left(123 \times \emptyset^{2}\right)\right\} \mu_{\text {water }} \\
& k_{\text {nanofluid }}=\frac{\left[\begin{array}{c}
\left\{k_{\text {nanoparticle }}\right\}+\left\{2 \times k_{\text {water }}\right\} \\
+\left\{2 \times\left(k_{\text {nanoparticle }}-k_{\text {water }}\right) \times \emptyset\right\}
\end{array}\right]}{\left[\begin{array}{c}
\left\{k_{\text {nanoparticle }}\right\}+\left\{2 \times k_{\text {water }}\right\} \\
-\left\{\left(k_{\text {nanoparticle }}-k_{\text {water }}\right) \times \emptyset\right\}
\end{array}\right]} \\
& P_{r, \text { nanofluid }}=\frac{\mu_{\text {nanofluid }} \times C_{p, \text { nanofluid }}}{k_{\text {nanofluid }}}
\end{aligned}
$$

\section{INTEGRATED RESEARCH METHODOLOGY}

The integrated methodology adopted to evaluate the effect of nanofluid on heat transfer characteristics of double pipe heat exchanger is presented below.

(1) Conduct the experiment using water as cold and hot fluid in double pipe heat exchanger as per the experimental procedure for double pipe heat exchanger. 
(2) Calculate the practical value of overall heat transfer coefficient as per calculation steps for experimental evaluation of overall heat transfer coefficient for water as cold and hot fluid.

(3) Calculate the theoretical value of overall heat transfer coefficient as per calculation steps for theoretical evaluation of overall heat transfer coefficient for water as cold and hot fluid.

(4) Empty the water from the tanks of the double pipe heat exchanger.

(5) For $0.001 \%$ volume concentration, prepare the nanofluid by mixing 0.833 grams of $\mathrm{Al}_{2} \mathrm{O}_{3}$ nanodispersion in water of 70 liters.

(6) Fill the nanofluid of $0.001 \%$ volume concentration into cold water tank. Now the nanofluid will work as cold fluid.

(7) Fill the water in hot water tank.

(8) Perform the experimentation and evaluate the overall heat transfer coefficient with nanofluid of $0.001 \%$ volume concentration as cold fluid and water as hot fluid as per the step number 1 to 4 of integrated research methodology.

(9) Perform the experimentation and evaluate overall heat transfer coefficient with nanofluid of $0.002 \%, 0.003$ $\%, 0.004 \%, 0.005 \%, 0.006 \%, 0.007 \%, 0.008 \%$, $0.009 \%$ and $0.01 \%$ volume concentration as per the step number 1 to 4 of integrated research methodology.

(10) Compare the overall heat transfer coefficient of water with nanofluid for different volume concentration.

\section{RESULTS AND DISCUSSION}

Actual experimentation on double pipe heat exchanger has been carried out as per integrated research methodology. The results for parallel flow and counter flow arrangements are presented in Table 2 and Table 3 respectively. The overall heat transfer coefficients obtained practically and theoretically are plotted for parallel flow arrangement in Figure 2 and 3 respectively and the same are plotted for counter flow arrangement in Figure 4 and Figure 5 respectively.

Table 2: Result for Parallel Flow Arrangement

\begin{tabular}{|c|c|c|c|c|c|}
\hline \multirow[t]{2}{*}{ 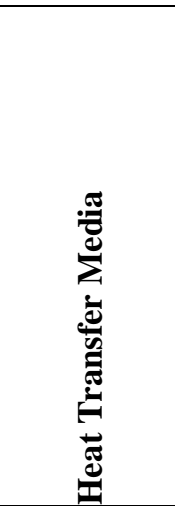 } & \multirow{2}{*}{ 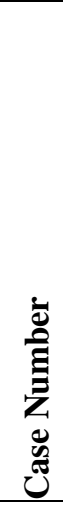 } & \multicolumn{2}{|c|}{ 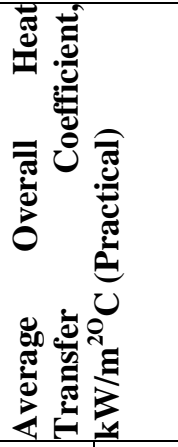 } & \multicolumn{2}{|c|}{ 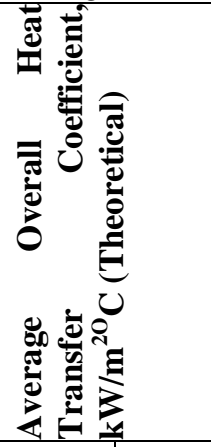 } \\
\hline & & Uo & $\mathrm{Ui}$ & Uo & $\mathrm{Ui}$ \\
\hline $\begin{array}{l}\text { Water to } \\
\text { Water }\end{array}$ & A & 0.27 & 0.32 & 16.13 & 19.35 \\
\hline $\begin{array}{l}\text { Nanofluid } \\
\text { of } \varphi=0.001\end{array}$ & B & 0.28 & 0.34 & 19.48 & 23.38 \\
\hline
\end{tabular}

\begin{tabular}{|l|l|l|l|l|l|}
\hline to Water & & & & & \\
\hline $\begin{array}{l}\text { Nanofluid } \\
\text { of } \varphi=0.002 \\
\text { to Water }\end{array}$ & $\mathrm{C}$ & 0.31 & 0.37 & 19.45 & 23.34 \\
\hline $\begin{array}{l}\text { Nanofluid } \\
\text { of } \varphi=0.003 \\
\text { to Water }\end{array}$ & $\mathrm{D}$ & 0.36 & 0.43 & 19.49 & 23.39 \\
\hline $\begin{array}{l}\text { Nanofluid } \\
\text { of } \varphi=0.004 \\
\text { to Water }\end{array}$ & $\mathrm{E}$ & 0.38 & 0.49 & 19.43 & 23.32 \\
\hline $\begin{array}{l}\text { Nanofluid } \\
\text { of } \varphi=0.005 \\
\text { to Water }\end{array}$ & $\mathrm{F}$ & 0.42 & 0.55 & 19.47 & 23.36 \\
\hline $\begin{array}{l}\text { Nanofluid } \\
\text { of } \varphi=0.006 \\
\text { to Water }\end{array}$ & $\mathrm{G}$ & 0.51 & 0.61 & 19.49 & 23.39 \\
\hline $\begin{array}{l}\text { Nanofluid } \\
\text { of } \varphi=0.007 \\
\text { to Water }\end{array}$ & $\mathrm{H}$ & 0.53 & 0.65 & 19.50 & 23.40 \\
\hline $\begin{array}{l}\text { Nanofluid } \\
\text { of } \varphi=0.008 \\
\text { to Water }\end{array}$ & $\mathrm{I}$ & 0.54 & 0.68 & 19.43 & 23.31 \\
\hline $\begin{array}{l}\text { Nanofluid } \\
\text { of } \varphi=0.009 \\
\text { to Water }\end{array}$ & $\mathrm{J}$ & 0.54 & 0.60 & 19.49 & 23.38 \\
\hline $\begin{array}{l}\text { Nanofluid } \\
\text { of } \varphi=0.01 \\
\text { to Water }\end{array}$ & $\mathrm{K}$ & 0.50 & 0.57 & 19.49 & 23.39 \\
\hline
\end{tabular}

Table 3: Result for Parallel Counter Arrangement

\begin{tabular}{|c|c|c|c|c|c|}
\hline \multirow[t]{2}{*}{ 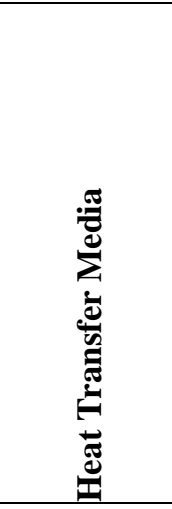 } & \multirow{2}{*}{ 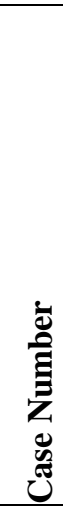 } & \multicolumn{2}{|c|}{ 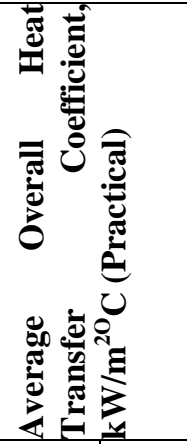 } & \multicolumn{2}{|c|}{ 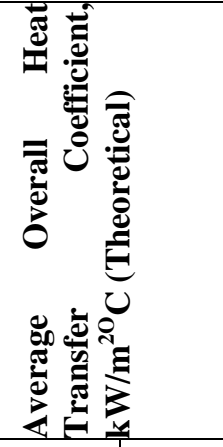 } \\
\hline & & Uo & $\mathrm{Ui}$ & Uo & Ui \\
\hline $\begin{array}{l}\text { Water to } \\
\text { Water }\end{array}$ & A & 0.36 & 0.43 & 19.21 & 23.05 \\
\hline $\begin{array}{l}\text { Nanofluid } \\
\text { of } \varphi=0.001 \\
\text { to Water }\end{array}$ & B & 0.42 & 0.52 & 23.49 & 19.57 \\
\hline $\begin{array}{l}\text { Nanofluid } \\
\text { of } \varphi=0.002 \\
\text { to Water }\end{array}$ & $\mathrm{C}$ & 0.49 & 0.61 & 23.48 & 19.57 \\
\hline $\begin{array}{l}\text { Nanofluid } \\
\text { of } \varphi=0.003 \\
\text { to Water }\end{array}$ & $\mathrm{D}$ & 0.54 & 0.69 & 23.51 & 19.59 \\
\hline $\begin{array}{l}\text { Nanofluid } \\
\text { of } \varphi=0.004 \\
\text { to Water }\end{array}$ & $\mathrm{E}$ & 0.59 & 0.76 & 23.28 & 19.40 \\
\hline $\begin{array}{l}\text { Nanofluid } \\
\text { of } \varphi=0.005 \\
\text { to Water }\end{array}$ & $\mathrm{F}$ & 0.68 & 0.81 & 23.33 & 19.44 \\
\hline
\end{tabular}




\begin{tabular}{|l|l|l|l|l|l|}
\hline $\begin{array}{l}\text { Nanofluid } \\
\text { of } \varphi=0.006 \\
\text { to Water }\end{array}$ & G & 0.75 & 0.90 & 23.51 & 19.59 \\
\hline $\begin{array}{l}\text { Nanofluid } \\
\text { of } \varphi=0.007 \\
\text { to Water }\end{array}$ & H & 0.83 & 0.99 & 23.47 & 19.56 \\
\hline $\begin{array}{l}\text { Nanofluid } \\
\text { of } \varphi=0.008\end{array}$ & I & 0.84 & 1.01 & 23.28 & 19.40 \\
\hline
\end{tabular}

\begin{tabular}{|l|l|l|l|l|l|}
\hline to Water & & & & & \\
\hline $\begin{array}{l}\text { Nanofluid } \\
\text { of } \varphi=0.009 \\
\text { to Water }\end{array}$ & $\mathrm{J}$ & 0.82 & 0.98 & 23.31 & 19.43 \\
\hline $\begin{array}{l}\text { Nanofluid } \\
\text { of } \varphi=0.01 \\
\text { to Water }\end{array}$ & $\mathrm{K}$ & 0.80 & 0.96 & 23.32 & 19.43 \\
\hline
\end{tabular}

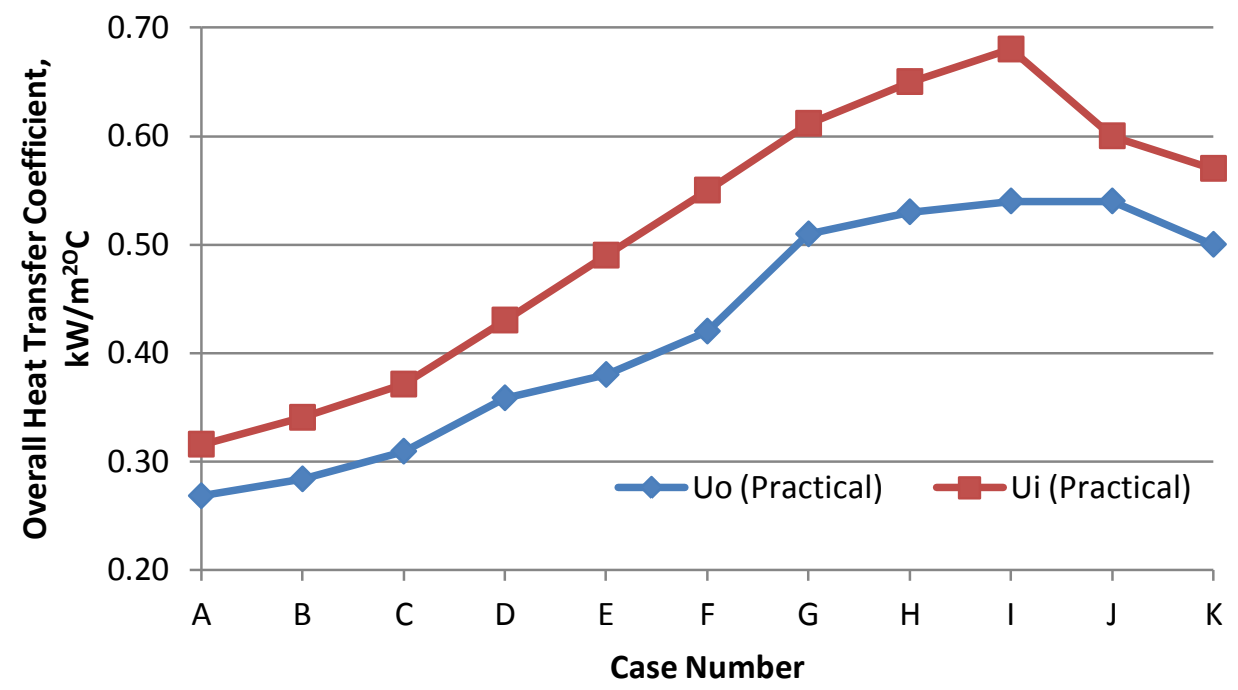

Fig 2: Practical Overall Heat Transfer Coefficients for Parallel Flow Arrangement

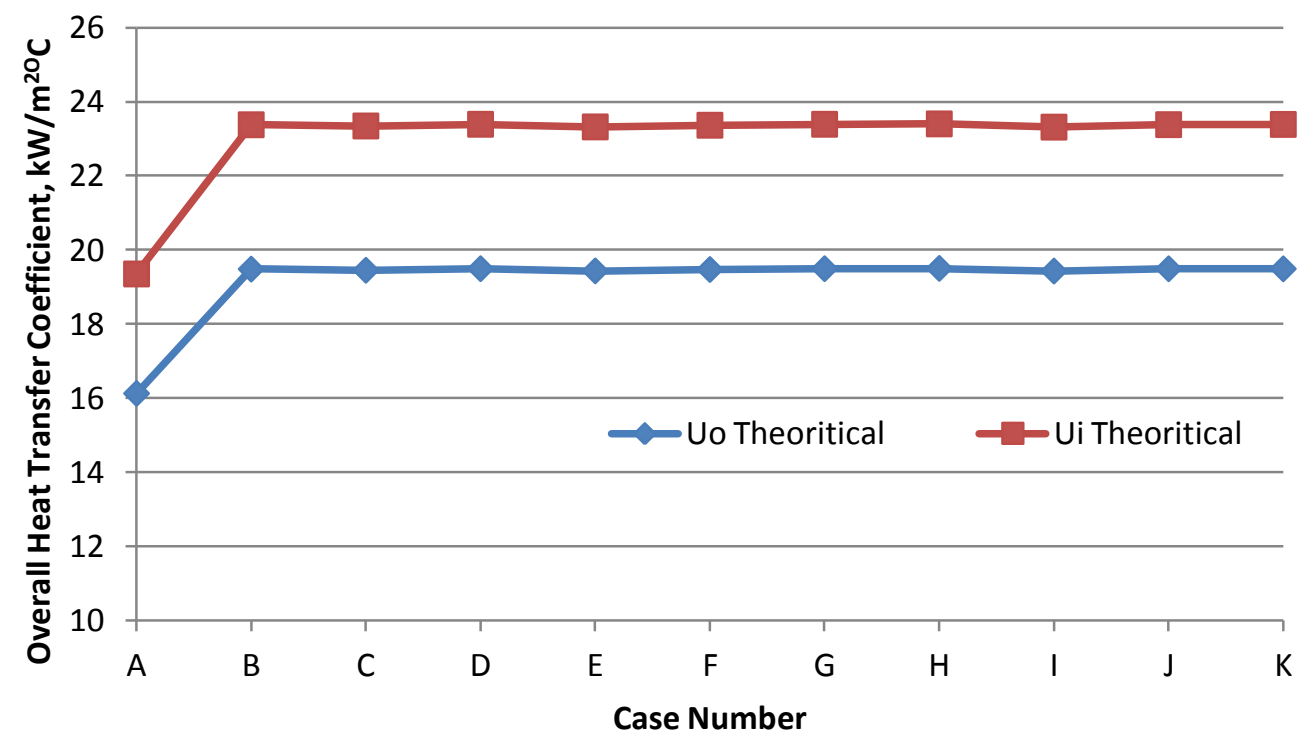

Fig 3: Theoretical Overall Heat Transfer Coefficients for Parallel Flow Arrangement 


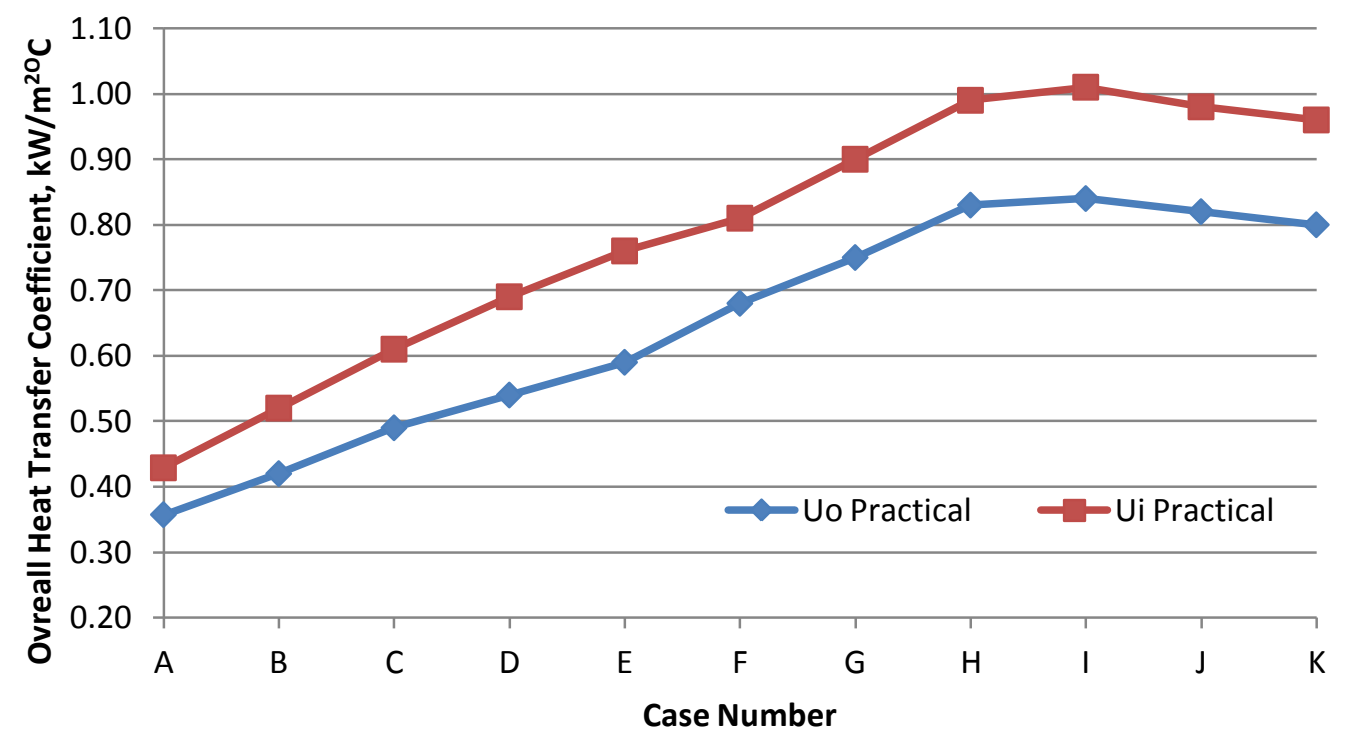

Fig 4: Practical Overall Heat Transfer Coefficients for Counter Flow Arrangement

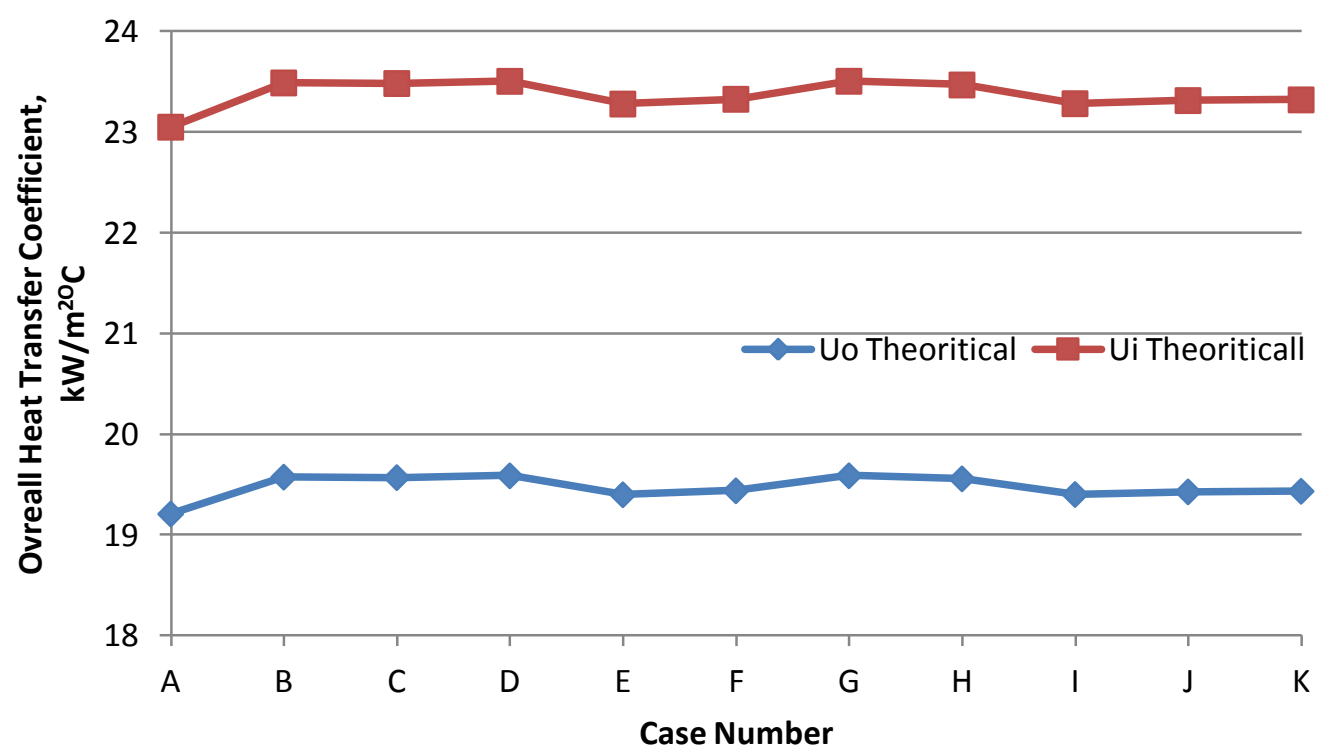

Fig 5: Theoretical Overall Heat Transfer Coefficients for Counter Flow Arrangement

The value of overall heat transfer coefficient increases in case of nanofluid of different volume concentrations to water heat transfer as compared to water to water heat transfer for parallel flow as well as counter flow arrangement for double pipe heat exchanger. The increase in outer and inner overall heat transfer coefficient is found to $101 \%$ and $115 \%$ in case of nanofluid having volume concentration of $0.008 \%$ for parallel flow and the same is found to be $135 \%$ and $136 \%$ in case of nanofluid having volume concentration of $0.008 \%$ for counter flow arrangement. It has been also observed that overall heat transfer coefficient increases up to nanofluid having volume concentration of $0.008 \%$ and then decreases for parallel flow and counter flow arrangement for double pipe heat exchanger.

\section{CONCLUSION}

An experimental investigation is carried out to determine the effect of various concentration of $\mathrm{Al}_{2} \mathrm{O}_{3}$ nano-dispersion mixed in water as base fluid on heat transfer characteristics of double pipe heat exchanger for parallel and counter flow arrangment. The volume concentrations of $\mathrm{Al}_{2} \mathrm{O}_{3}$ nanofluid prepared are $0.001 \%$ to $0.01 \%$. The conclusion derived for the study is that overall heat transfer coefficient increase with increase in volume concentration of $\mathrm{Al}_{2} \mathrm{O}_{3}$ nanodispersion compared to water up to volume concentration of $0.008 \%$ and then decreases. The effect of $\mathrm{CuO}$ nanoparticles on heat transfer characteristics of double pipe heat exchanger for parallel and counter flow arrangement are presented in part II of the paper. 


\section{ACKNOWLEDGEMENTS}

The authors are extremely thankful to the staff members of Mechanical Engineering Department, A. D. Patel Institute of Technology, New Vallabh Vidyanagar for providing the useful resources and the management of the college and Charutar Vidya Mandal for providing financial support to carry out the experimentation work. The authors have also approached to GUJCOST for financial support. The authors are also thankful to the students of the college for providing their untiring support and efforts wherever needed.

\section{REFERENCES}

[1]. L. Léal, M. Miscevic, P. Lavieille, M. Amokrane, F. Pigache, F. Topin, B. Nogarède and L. Tadrist, An overview of heat transfer enhancement methods and new perspectives: Focus on active methods using electroactive materials, Internanational Journal of Heat and Mass Transfer, 61, 2013, pp. 505-524.

[2]. Wael I. A. Aly, Numerical study on turbulent heat transfer and pressure drop of nanofluid in coiled tubein-tube heat exchangers, Energy Conversion and Management, Volume 79, March 2014, Pages 304316.

[3]. A. Rabienataj Darzi, Mousa Farhadi and Kurosh Sedighi, Heat transfer and flow characteristics of AL2O3-water nanofluid in a double tube heat exchanger, International Communications in Heat and Mass Transfer, Volume 47, October 2013, Pages 105112.

[4]. M. Akhtari, M. Haghshenasfard and M. R. Talaie, Numerical and Experimental Investigation of Heat Transfer of $\alpha-\mathrm{Al} 2 \mathrm{O} 3 /$ Water Nanofluid in Double Pipe and Shell and Tube Heat Exchangers, Numerical Heat Transfer, Part A: Applications: An International Journal of Computation and Methodology, Volume 63, Issue 12, 2013, pages 941-958.

[5]. Byung-Hee Chun, Hyun Uk Kang and Sung Hyun Kim, Effect of alumina nanoparticles in the fluid on heat transfer in double pipe heat exchanger system, Korean Journal of Chemical Engineering, 25(5),2008, pp. 966-971.

[6]. Reza Aghayari, Heydar Maddah, Fatemeh Ashori, Afshin Hakiminejad and Mehdi Aghili, Effect of nannoparticles on heat transfer in mini double pipe heat exchangers in turbulent flow, Heat Mass Transfer, 2013, DOI 1007-2Fs00231-014-1415-0.

[7]. Weerapun Duangthongsuk and Somchai Wongwises, Heat transfer enhancement and pressure drop characteristics of $\mathrm{TiO} 2-$ water nanofluid in a doubletube counter flow heat exchanger, International Journal of Heat and Mass Transfer, Volume 52, Issues 7-8, March 2009, Pages 2059-2067

[8]. Rohit S. Khedkar, Shriram S. Sonawane and Kailas L. Wasewar, Heat transfer study on concentric tube heat exchanger using TiO2-water-based nanofluid, International Communications in Heat and Mass Transfer, In Press, Uncorrected Proof, Available online 16 July 2014
[9]. Mehdi Bahiraei and Morteza Hangi, Investigating the efficacy of magnetic nanofluid as a coolant in doublepipe heat exchanger in the presence of magnetic field, Energy Conversion and Management, Volume 76, December 2013, Pages 1125-1133

[10]. M. Chandra Sekhara Reddy and Veeredhi Vasudeva Rao, Experimental investigation of heat transfer coefficient and friction factor of ethylene glycol water based $\mathrm{TiO} 2$ nanofluid in double pipe heat exchanger with and without helical coil inserts, International Communications in Heat and Mass Transfer, Volume 50, January 2014, Pages 68-76.

[11]. Liping Liu, Eung Soo Kim, Young-Gil Park and Anthony M. Jacobi, The Potential Impact of Nanofluid Enhancements on the Performance of Heat Exchangers, Heat Transfer Engineering, Volume 33, Issue 1, 2012, pages 31-41

[12]. M.M. Elias, I.M. Shahrul, I.M. Mahbubul, R. Saidur and N.A. Rahim, Effect of different nanoparticle shapes on shell and tube heat exchanger using different baffle angles and operated with nanofluid, International Journal of Heat and Mass Transfer, Volume 70, March 2014, Pages 289-297.

[13]. Jaafar Albadr, Satinder Tayal and Mushtaq Alasadi, Heat transfer through heat exchanger using Al2O3 nanofluid at different concentrations, Case Studies in Thermal Engineering, Volume 1, Issue 1, October 2013, Pages 38-44.

[14]. Roghayeh Lotfi, Ali Morad Rashidi and Azadeh Amrollahi, Experimental study on the heat transfer enhancement of MWNT-water nanofluid in a shell and tube heat exchanger, International Communications in Heat and Mass Transfer, Volume 39, Issue 1, January 2012, Pages 108-111

[15]. K. Y. Leong, R. Saidur, T.M.I. Mahlia and Y.H. Yau, Modeling of shell and tube heat recovery exchanger operated with nanofluid based coolants, International Journal of Heat and Mass Transfer, Volume 55, Issue 4, 31 January 2012, Pages 808-816

[16]. Mehdi Bahiraei, Seyed Mostafa Hosseinalipour and Mahdi Saeedan, Prediction of Nusselt Number and Friction Factor of Water-Al2O3 Nanofluid Flow in Shell-and-Tube Heat Exchanger with Helical Baffles, Chemical Engineering Communications

[17]. I. M. Shahrul, I. M. Mahbubul, R. Saidur, S. S. Khaleduzzaman, M. F. M. Sabri, and M. M. Rahman, Effectiveness Study of a Shell and Tube Heat Exchanger Operated with Nanofluids at Different Mass Flow Rates, Numerical Heat Transfer, Part A: Applications: An International Journal of Computation and Methodology, Volume 65, Issue 7, 2014, pages 699-713

[18]. F.S. Javadi, S. Sadeghipour, R. Saidur, G. BoroumandJazi, B. Rahmati and M.M. Elias, M.R. Sohel, The effects of nanofluid on thermophysical properties and heat transfer characteristics of a plate heat exchanger,International Communications in Heat and Mass Transfer, Volume 44, May 2013, Pages 5863 
[19]. Shahabeddin K. Mohammadian and Yuwen Zhang, Analysis of nanofluid effects on thermoelectric cooling by micro-pin-fin heat exchangers, Applied Thermal Engineering, Volume 70, Issue 1, 5 September 2014, Pages 282-290

[20]. Y. Vermahmoudi, S. M. Peyghambarzadeh, S.H. Hashemabadi and M. Naraki, Experimental investigation on heat transfer performance of $\mathrm{Fe}_{2} \mathrm{O}_{3}$ /water nanofluid in an air-finned heat exchanger, European Journal of Mechanics B/Fluids, Volume 44, March-April 2014, Pages 3241.

[21]. Arun Kumar Tiwari, Pradyumna Ghosh and Jahar Sarkar, Heat transfer and pressure drop characteristics of $\mathrm{CeO} 2 /$ water nanofluid in plate heat exchanger, Applied Thermal Engineering, Volume 57, Issues 12, August 2013, Pages 24-32

[22]. Z. Taghizadeh Tabari and S. Zeinali Heris, Heat Transfer Performance of Milk Pasteurization Plate Heat Exchangers Using MWCNT/Water Nanofluid, Journal of Dispersion Science and Technology

[23]. Shive Dayal Pandey and V.K. Nema, Experimental analysis of heat transfer and friction factor of nanofluid as a coolant in a corrugated plate heat exchanger, Experimental Thermal and Fluid Science, Volume 38, April 2012, Pages 248-256

[24]. M. Khoshvaght-Aliabadi, F. Hormozi and A. Zamzamian, Effects of geometrical parameters on performance of plate-fin heat exchanger: Vortexgenerator as core surface and nanofluid as working media, Applied Thermal Engineering, Volume 70, Issue 1, 5 September 2014, Pages 565-579.

[25]. T. Srinivas and A. Venu Vinod, Performance of an agitated helical coil heat exchanger using Al2O3/water nanofluid, Experimental Thermal and Fluid Science, Volume 51, November 2013, Pages 77-83.

[26]. Ching-Song Jwo, Lung-Yue Jeng, Tun-Ping Teng and Chien-Chih Chen, Performance of overall heat transfer in multi-channel heat exchanger by alumina nanofluid, Journal of Alloys and Compounds, Volume 504, Supplement 1, August 2010, Pages S385-S388

[27]. J. Zhang, Y.H. Diao, Y.H. Zhao, X. Tang, W.J. Yu and S. Wang, Experimental study on the heat recovery characteristics of a new-type flat micro-heat pipe array heat exchanger using nanofluid, Energy Conversion and Management, Volume 75, November 2013, Pages 609-616

[28]. H.A. Mohammed and K. Narrein, Thermal and hydraulic characteristics of nanofluid flow in a helically coiled tube heat exchanger, International Communications in Heat and Mass Transfer, Volume 39, Issue 9, November 2012, Pages 1375-1383

[29]. A.G. Agwu Nnanna, William Rutherford, Wessam Elomar and Brian Sankowski, Assessment of thermoelectric module with nanofluid heat exchanger, Applied Thermal Engineering, Volume 29, Issues 23, February 2009, Pages 491-500
[30]. Stella Jesumathy, M Udaykumar and S. Suresh, Experiemental study of enhanced heat transfer by addition of $\mathrm{CuO}$ nanoparticle, Heat and Mass Transfer, 48, 2012, pp. 965-978.

[31]. L. Shyam Sunder and Manoj K. Singh, Convective heat transfer and friction factor correlations of nanofluid in tube and with inserts : A review, Renewable and Sustainable Energy Reviews, 20, 2013, pp. 23-35.

\section{BIOGRAPHIES}

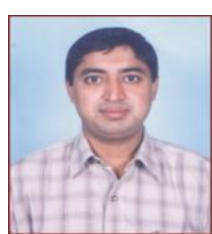

Dr. N. K. Chavda has completed M. E. (Mech) from SVNIT, Surat and Ph. D. from The M. S. University of Baroda. He has 19 years of teaching experience and published many papers in International Journals/Conference. He has been awarded with Best Polytechnic Teacher by ISTE, New Delhi.

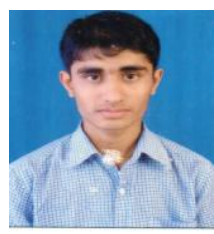

Jay R. Patel is final year student of Mechanical Engineering Department of A. D. Patel Institute of Technology, New Vallabh Vidyanagar. His areas of interest are maintenance, thermal and design.

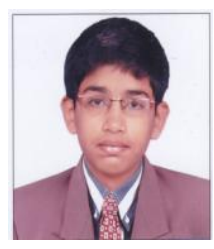

Hardik H. Patel is final year student of Mechanical Engineering Department of A. D. Patel Institute of Technology, New Vallabh Vidyanagar. His areas of interest are maintenance and production.

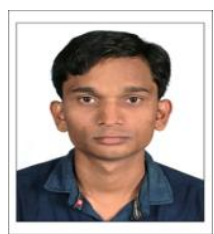

Atul P. Parmar is final year student of Mechanical Engineering Department of A. D. Patel Institute of Technology, New Vallabh Vidyanagar. His areas of interest are maintenance, production and thermal engineering. 